\title{
SUPERIMPOSISI SEFALOMETRI PADA MALOKLUSI SKELETAL KELAS III DENGAN BEDAH ORTOGNATIK
}

\author{
Albert Suryaprawira \\ Departemen Ortodonsia, Fakultas Kedokteran Gigi, Universitas Prof. Dr. Moestopo (Beragama), Jakarta \\ Korespondesi: Albert Suryaprawira,dr_alberts@yahoo.com
}

\begin{abstract}
ABSTRAK
Latar belakang: pasien yang memerlukan koreksi maloklusi skeletal kelas III dengan perawatan badah ortognatik umumnya sangat kompleks bagi seorang ortodontis. Sangatlah penting untuk mendapatkan hasil yang baik dari segi estetik dan fungsi. Laporan kasus: pasien laki-laki 17 tahun yang mengalami kesulitan berbicara dan saat mengunyah makanan. Pasien memiliki profil wajah dengan rahang bawah yang panjang. Gambaran radiografis sefalometri sebelum perawatan diambil untuk menganalisis maloklusi skeletal, mengukur jarak potongan tulang saat pembedahan, dan prediksi dari respon jaringan lunak. Panoramik radiografis juga diambil untuk menganalisa kualitas tulang, kelainan tulang, impaksi molar ketiga. Sebelum pembedahan, dilakukan pengambilan kembali sefalometri untuk mengevaluasi kembali rencana perawatan, dan memastikan potongan tulang. Setelah pembedahan, dilakukan pengambilan sefalometri kembali untuk mengkonfirmasi perawatan yang telah dilakukan. Superimposisi dari sefalomatri tersebut diatas dilakukan untuk menganalisa hasil perawatan. Antara lain untuk mengukur banyaknya pergerakan dari tulang dan jaringan lunak. Pasien juga harus mamahami rencana pembedahan, hasil yang didapat, dan pencegahan relaps. Pada pasien ini dilakukan operasi mandibular setback. Kesimpulan: pasien yang memiliki diskrepansi yang cukup berat dapat dilakukan teknik perawatan bedah ortognatik. Hasil yang didapat cukup memuaskan secara estetik dan stabilitasnya.
\end{abstract}

Kata kunci: superimposisi, sefalometri, mandibular setback

\begin{abstract}
Background: patients requiring correction of large Class III skeletal discrepancy mainly has been among the most complicated treatments for orthodontists. Correction of aesthetic and functional problem is especially crucial. Case report: this is a case report of an adult male aged 17 years who complained of difficulty in chewing and speaking. Patient has a mandibular prominent profile (concave). The pre-treatment cephalometry radiograph was taken to analyze the skeletal problem and to measure the amount of bone movement and the prediction soft tissue response. The panoramic radiograph was also taken to analyze bone quality, bone abnormality, third molar impaction, etc. Before the surgery, the pre-surgical cephalometry radiograph was taken to re-evaluate the plan and to settle the final amount of bone cut. After the surgery, the post-surgical cephalometry radiograph was taken to confirm the result with the plan. The superimposition between those radiographs was performed to analyze the outcome. The superimposition is important to describe the amount of hard and soft tissue movement. It is also important to predict the possibility of relapse after the surgery. The patient needs to understand all the surgical plan, outcome and relapse prevention. The surgery included was mandibular setback. Conclusion: although the discrepancy was severe using this combination of treatment and radiographic superimposition, an aesthetically pleasing and stable result was achieved.
\end{abstract}

Keywords: superimposition, cephalometry, mandibular setback

\section{PENDAHULUAN}

D alam populasi masyarakat dewasa ini, malolusi kelas III adalah kelainan skeletal yang kompleks untuk dilakukan perawatan. Angka insidensi pada ras kaukasoid adalah 5\%. Penyebab dari kelainan ini biasanya faktor genetik atau keturunan. Pasien dengan gejala klinis maloklusi kelas III memperlihatkan gejala kelainan dalam hubungan rahang dan juga hubungan dento-alveolar. Telah banyak dilaporkan bentuk pengukuran sefalometri untuk kelainan tersebut antara lain adalah panjang basis kranium bagian anterior yang berkurang, nilai 
sudut SNA yang kecil, rahang atas dengan posisi retrusif dan berukuran kecil, inklinasi gigi insisif anterior atas yang proklinasi, inklinasi gigi insisif bawah yang retroklinasi dan ukuran 1/3 wajah bagian bawah yang lebih panjang. ${ }^{2}$ Hubungan gigi geligi mempunyai jarak gigit yang negatif, inklinasi gigi insisif atas yang proklinasi dan inklinasi gigi insisif bawah yang retroklinasi. ${ }^{3}$

Maloklusi skeletal kelas III dapat berupa rahang atas yang retrusi, rahang bawah yang protrusi atau kombinasi keduanya. Bentuk dari rotasi mandibula adalah ke arah belakang dan adanya pertumbuhan yang berlebih dalam arah vertikal. ${ }^{3}$ Dibutuhkan perencanaan perawatan yang baik, koodinasi terintegrasi dengan berbagai bidang ilmu dan depertemen lainnya serta kerjasama dengan pasien. Umumnya pasien mengeluh ketidaknyamanan dalam hal estetik atau penampilan dan biasanya diikuti dengan gangguan fungsi kunyah dan ganguan sendi temporomandibular. ${ }^{4.5,6}$ Dalam makalah ini, penulis ingin menjabarkan secara komprehensif pasien dengan kelainan maloklusi kelas III namun dari segi perubahan yang dianalisa menggunakan radiografi sefalometri.

\section{LAPORAN KASUS}

Seorang pasien laki-laki usia 17 tahun datang ke Departemen Ortodonti, dengan keluhan utama tidak menyukai penampilan wajahnya dan kesulitan dalam pengunyahan. Pasien mempunyai motivasi yang sangat baik untuk mendapatkan perawatan yang optimal. Secara umum pasien dalam kondisi sehat. Pemeriksaan ekstraoral memperlihatkan pasien dengan kelainan maloklusi kelas III, ukuran rahang bawah yang besar, profil wajah cekung. Pasien mempunyai bibir yang kompeten, ukuran sudut nasolabial yang normal, dengan dagu yang maju dan sedikit miring kearah sisi kiri. Penampilan gigi anterior atas berkurang. Kebersihan mulut pasien secara umum baik dan tidak ditemukan kelainan sendi temporomandibula. Pasien kemudian diminta untuk hadir pada klinik integrasi ortodonti dan bedah mulut. Total lamanya perawatan sekitar 2 tahun 8 bulan.

Pemeriksaan intraoral memperlihatkan gigi berjejal pada rahang atas dan rahang bawah dengan ukuran jarak gigit 2,5 mm dan ukuran tumpang gigit $7 \mathrm{~mm}$. Hubungan gigi molar pertama permanen kelas III kanan dan kiri. Terdapat gigitan silang pada regio anterior dan posterior.

Pemeriksaan sefalometri menunjukkan sudut SNA sebesar $86^{\circ}$, SNB sebesar $90^{\circ}$, nilai ANB $-4^{\circ}$, inklinasi insisif rahang atas terhadap bidang maksila sebesar $121^{\circ}$, inklinasi insisif rahang bawah terhadap bidang mandibula $77^{\circ}$, rasio tinggi wajah $57 \%$.

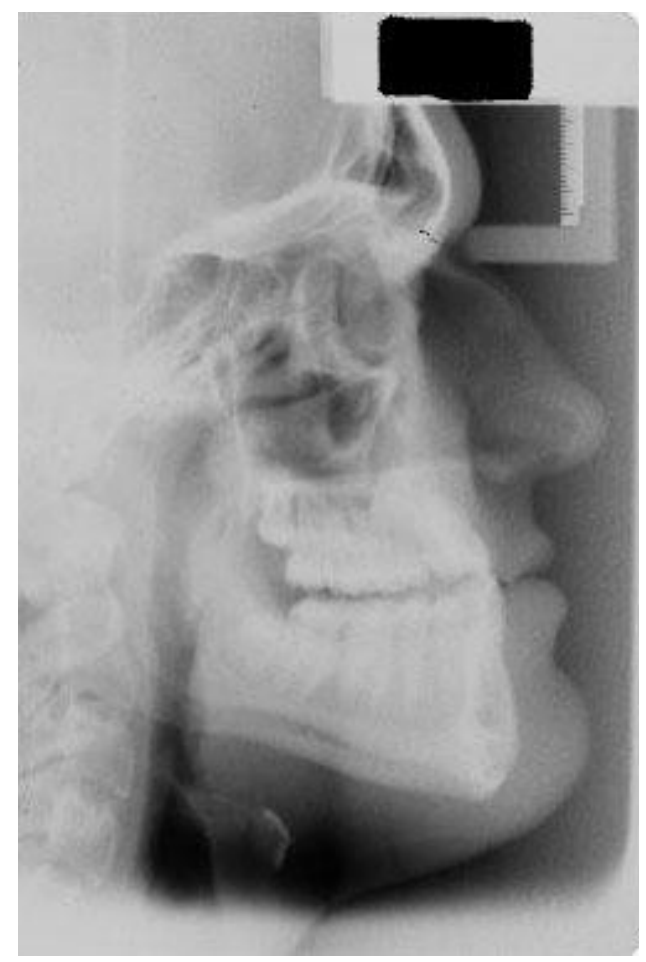

Gambar 1. Foto sefalometri sebelum perawatan.

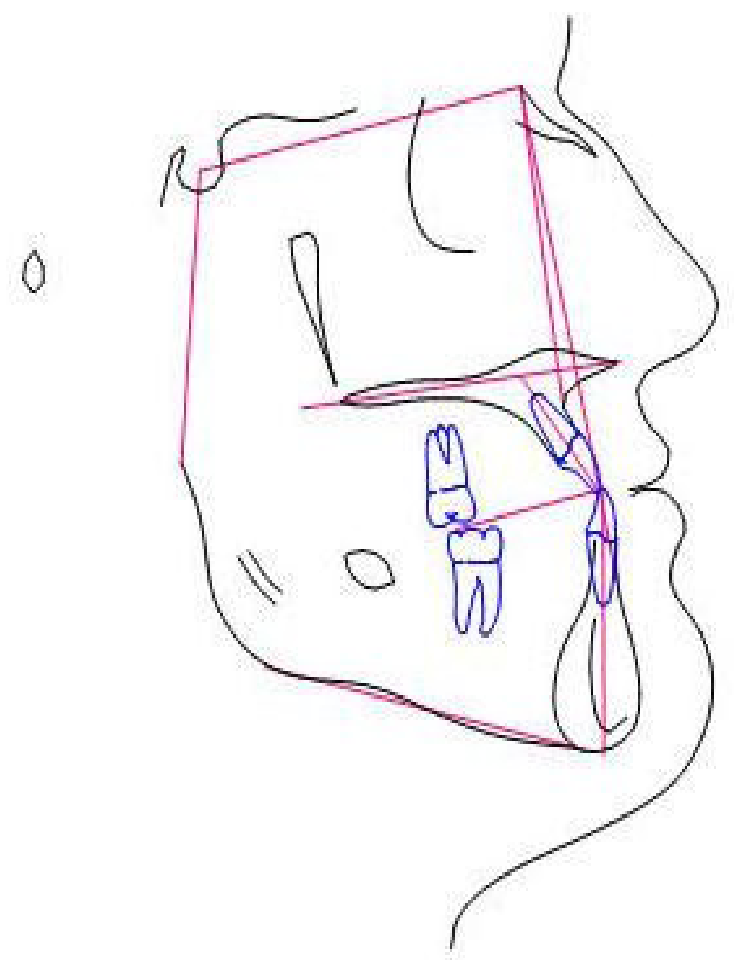

Gambar 2. Tracing sefalometri sebelum perawatan.

\section{PENATALAKSANAAN}

Tujuan dari perawatan ini adalah mempertahankan kebersihan mulut yang optimal, mengembalikan fungsi dan estetik dari gigi dan wajah, dan operasi pada molar tiga bawah permanen kanan dan kiri karena daerah tersebut akan dipakai untuk pemotongan tulang. Perawatan ortodonti diperlukan 
untuk merapikand an dekompensasi gigi geligi atas dan bawah serta koordinasi rahang atas dan bawah. Kemudian dilakukan pembedahan untuk mengoreksi kelainan hubungan rahang dengan bilatterral sagital split osteotomies mandibular set back. Rahang bawah dimundurkan sebanyak $7 \mathrm{~mm}$ dengan disertai autorotasi mandibula kearah oklusi sentrik.

Setelah perawatan didapat hasil sefalometri sebagai berikut: sudut SNA sebesar $86^{\circ}$, SNB sebesar $85^{\circ}$, nilai ANB $1^{\circ}$, inklinasi insisif rahang atas terhadap bidang maksila sebesar $123^{\circ}$, inklinasi insisif rahang bawah terhadap bidang mandibula $91^{\circ}$, rasio tinggi wajah $55 \%$.

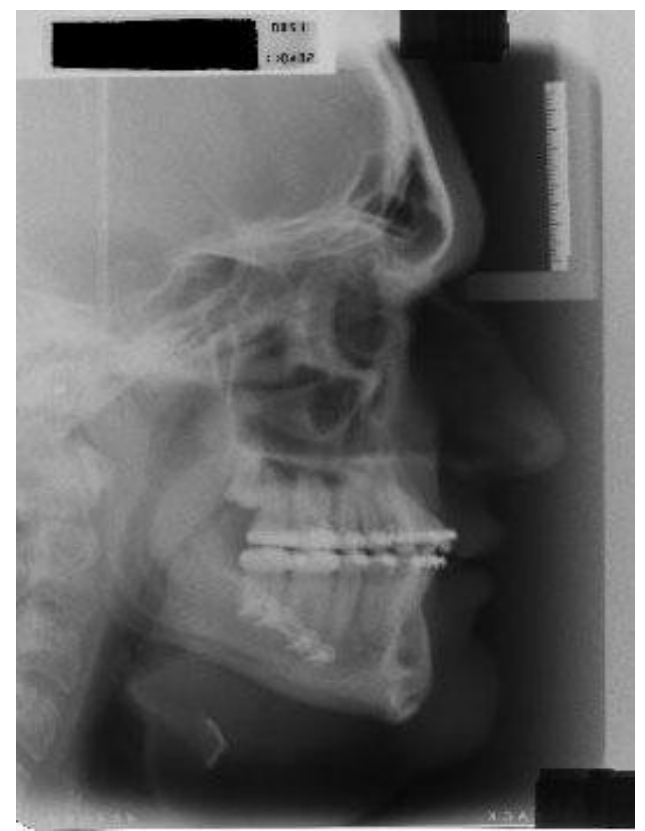

Gambar 3. Foto sefalometri setelah pembedahan.

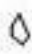

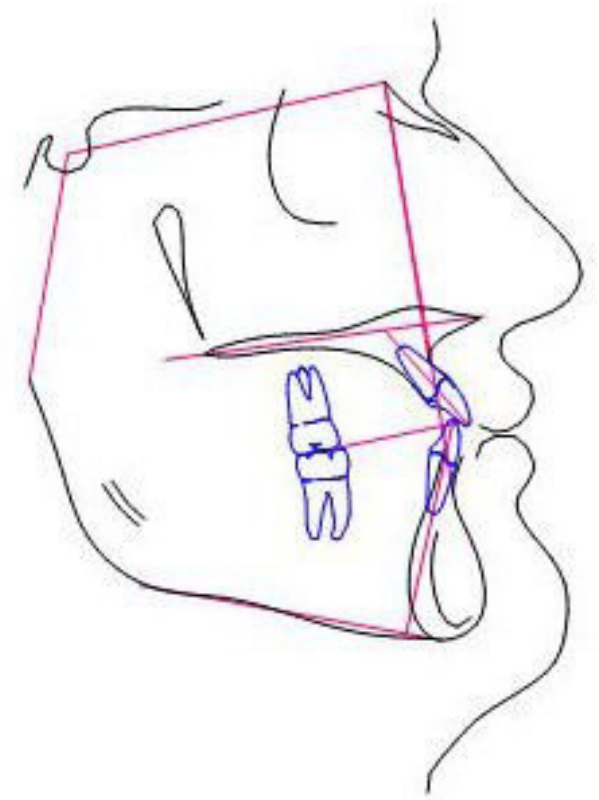

Gambar 4. Tracing sefalometri setelah perawatan.

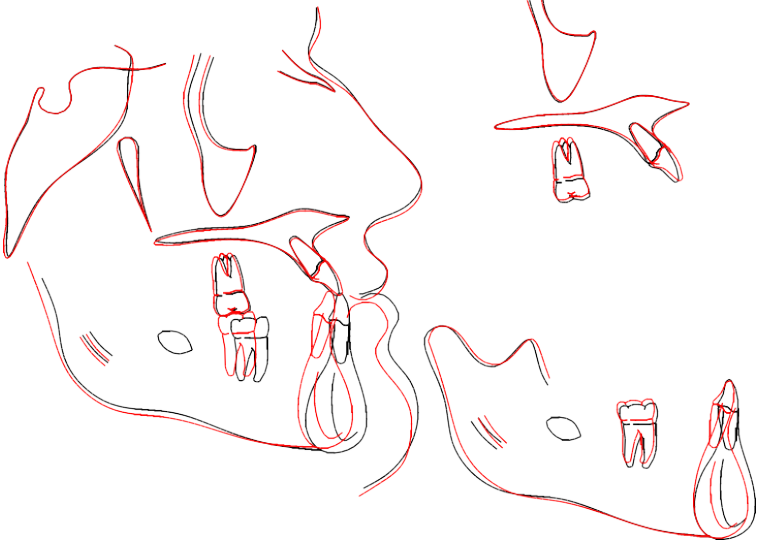

Gambar 5. Superimposisi radiografi sebelum dan sesudah perawatan.

\section{PEMBAHASAN}

Setelah perawatan selesai, dilakukan evaluasi terhadap hasil yang didapat. Keluhan pasien yaitu penampilan wajah dan kesulitan dalam pengunyahan dapat teratasi. Bentuk dan ukuran rahang bawah telah terkoreksi dengan baik dengan adanya pergerakan mandibula kearah belakang. Jarak gigit pasien normal juga dengan tumpang gigitnya.

Gambaran superimposisi hasil tracing dari rontgen sefalometri didapat hasil yang baik. Sudut SNA relatif tidak berubah. Sudut SNB berkurang dari $90^{\circ}$ ke $85^{\circ}$ yang merupakan ukuran dari keberhasilan perawatan. Nilai ANB menjadi normal yaitu $1^{\circ}$. Inklinasi gigi insisif atas terhadap bidang maksila juga relatif stabil. Namun nilai inklinasi gigi insisif bawah terhadap bidang mandibular bertambah sekitar $14^{\circ}$ yang terjadi akibat proses dekompensasi. Ukuran ketinggian wajah juga berkurang namun tidak banyak berubah.

Pembedahan dilakukan dengan teknik bilateral split osteotomi pada mandibula dengan memundurkan mandibula $7 \mathrm{~mm}$ ke arah belakang. Tidak ditemukan kelainan pada nervus alveolaris inferior setelah operasi meskipun ada risiko $20 \%$ yang telah diinformasikan kepada pasien.9

Dilakukan kontrol setelah pembedahan setelah 1 minggu. Kemudian tahap penyelesaian dengan ortodonti selama 2 bulan. Setelah 8 minggu pasien kembali dipanggil untuk melihat kemungkinan adanya relapse. 10

\section{KESIMPULAN}

Pasien yang memiliki kelainan maloklusi skeletal kelas III umumnya dirawat dengan perawatan kombinasi antara ortodonti dan bedah rahang. Pembedahan pada rahang bawah umumnya sering dilakukan, namun dapat dikombinasikan dengan bedah rahang. Hasil penilaian pada pasien ini 
didapat hasil yang cukup memuaskan baik dari segi fungsi stomatognatik maupun estetika. Keberhasilan perawatan yang didapat cukup stabil.

Gambaran superimposisi hasil tracing dari sefalometri diperoleh hasil yang baik. Sudut SNB berkurang dari $90^{\circ} \mathrm{ke} 85^{\circ}$ yang merupakan ukuran dari keberhasilan perawatan. Nilai ANB menjadi normal yaitu $1^{\circ}$. Inklinasi gigi insisif atas terhadap bidang maksila juga relatif stabil. Namun nilai inklinasi gigi insisif bawah terhadap bidang mandibular bertambah sekitar $14^{\circ}$ yang terjadi akibat proses dekompensasi. Ukuran ketinggian wajah juga berkurang namun tidak banyak berubah.

Superimposisi dapat dilakukan untuk mengevaluasi keberhasilan perawatan dan mengetahui semua perubahan yang terjadi pada gigi dan tulang. Dapat pula digunakan untuk mencegah terjadinya relapse di kemudian hari. Untuk penelitian lebih lanjut, mungkin perlu dilakukan penelitian untuk membedakan hasil superimposisi pada jaringan lain atau komparasi hasil sefalometri manual dan digital.

\section{DAFTAR PUSTAKA}

1. Ayoub AF, Millett DT, Hasan S. Evaluation of skeletal stability following surgical correction of mandibular prognathism. Br J Oral Maxillofac Surg. 2000:38:305-311.

2. Hopkins $\mathrm{GB}$ et al. The cranial base as an aetiological factor in malocclusion. Angle Orthodontics. 1968:38:250-255.

3. Guyer EC et al. Components of class III malocclusion in juveniles and adolescents. Angle Orthodontics. 1986:56:7-30.

4. Trauner $\mathrm{R}$ danObwegeser $H$. Surgical correction of mandibular prognathism and retrogenia with consideration of genioplasty. Oral Surg Oral Med Oral Path. 1957:10:671-692.

5. Epker BN dan Wolford LM. Middle third facial osteostomies. J Oral Surg. 1975:33:491-514.

6. Proffit WR et al. Surgical versus orthodontic correction. IJAOOS. 1992:7:209-220.

7. Sarver DM et al. Video Imaging for planning and counseling in orthognathic surgery. J Oral Maxillofac Surg. 1988:49:939-945.

8. Hunt NP danRudge SJ. Facial profile and orthognathic surgery. BJO. 1984:11:126- 136.

9. Tucker MR et al. Rigid fixation for maxillofacial surgery. 1991. JB Lippincott, Philadelphia.

10. Fish LC danEpker BN. Prevention of relapse in surgical orthodontic treatment. JCO. 1986:20:826-884. 